Covered in: Web of Sciences (WOS); EBSCO; ERIH+; Google Scholar; Index Copernicus; Ideas RePeC; Econpapers; Socionet; CEEOL; Ulrich ProQuest; Cabell, Journalseek; Scipio; Philpapers; SHERPA/RoMEO repositories; KVK; WorldCat; CrossRef; CrossCheck

2019, Volume 11, Issue 1, pages: 88-99 | doi: https://doi.org/10.18662/rrem/98

\section{Inclusion of Roma Students in Romanian Schools - Examples of Good Practice}

\section{Maria GOGA ${ }^{1}$}

${ }^{1}$ Associate Professor, Technical University of Civil Engineering of Bucharest, Bucharest, Romania, goga.maria@yahoo.com
Abstract: In this paper we aim to identify ways to prevent and manage the inequality in education of Roma students. The research was based on the application of a questionnaire and an interview to teachers teaching Roma students in schools. The results of the survey and interview highlights important issues related to the discrimination of Roma students from both students and teachers. In addition, the responding teachers offer timely attempts to prevent and manage different types of discrimination against Roma students. The main ways of manifesting inequalities in Roma students, as teachers perceive, are the prejudices related to the social status of the Roma, the financial situation, as well as their isolation in communities far from the Romanian pupils. The article presents examples of good practices on preventing and managing discrimination situations for Roma students at school level.

Keywords: Roma students; inequalities; integration; good practices; school.

How to cite: Goga, M. (2019). Inclusion of Roma Students in Romanian Schools - Examples of Good Practice. Revista Romaneasca pentru Educatie Multidimensionala, 11(1), 88-99. https://doi.org/10.18662/rrem/98 



\section{Introduction}

One of the categories of population severely affected by the phenomenon of reduced participation in education is Roma ethnicity. Roma are the second most diversified ethnic and cultural group in Romania, after the Hungarian one. This minority represents $2-3 \%$ of Romania's population. Most of the Roma have renounced to their traditional style, some of them being united with other Romanians or other minorities, thus reducing the official number of Roma declared. Socially there are significant differences between Roma sub-groups. Despite these differences, some groups continue to be socially, economically and educationally marginalized.

State of the Art - The same situation as in Romania exists in Europe as well and worldwide. For example (Kirova \& Thorlakson, 2015) expresses the fact that similar challenges as in Romania exists in other educational systems such as the ones from USA, EU, Canada. In Europe, estimations shows that there are around 11 millions Romani inhabitants living on its territory, from which around $70 \%$ are living in Eastern Europe (Amnesty International, 2013). The Romani people have a rich culture, diverse traditions, customs, religions and languages. In EU there exist a large number of initiatives that were made during the years 2005-2015 under Roma Inclusion Declaration (European Parliament, 2015). This includes the integration of Roma in different key fields such as health, employment, reduction of poverty etc. A key role between those fields has the education. Responsible decision factors should take care of the integration of Roma in the different educational systems from Europe. Among the integration initiatives, it can be mentioned the SEDRIN project (Friedman \& Friedman, 2015) that run during a period of two-years (October 2012 to October 2015) and involved several countries: Hungary, Spain, Romania, Italy, Portugal, Greece and Cyprus. The special emphasis of SEDRIN was on Roma woman that should be seen as a way to mediate between their children and education. As a result of the project a methodology handbook was written to be used further for the integration of Roma children. Despite efforts done in this area, however, this target still needs to be fully accomplished. In the paper (Miskovic \& Curcic, 2016) it is stated that several tensions exists for a complete integration of Roma people. Regarding educational system, the tensions are: "(b) between policy planning vs. policy implementation; and (c) between making schools ready for students and students ready for schools" (Miskovic, 2016). Summarizing it can be concluded that similar challenges as in Romania exist in the European Union and World Wide. This paper reports about the 
finding of a study that done in Romania regarding the integration of Roma people in the schools.

The inclusion of Roma people is needed by some reasons. One of them is the discrimination of this ethnic group. Unfortunately, the Roma people are part of a stigmatized ethnic group. Their discrimination is due stereotypes and prejudices about the Roma. According to Leyens, Yzerbyt and Schadron (1994), the stereotype is a set of shared beliefs about the characteristics of some people, personality traits and behavior, specific to a group of people. J. Duckitt (1992) provides some reasons why the stereotype is "bad". Some of these are: a misguided or incorrect generalization, a rigid or inflexible attitude, and an irrational attitude that justifies discrimination.

Social judgeability theory holds that people rely on naive theories when forming impressions (Yzerbyt, Leyens \& Schadron, 1997). This could be the case of judging Roma students on the sole basis of the stereotypes of the perceivers. For most of the Roma students the entry into Roma public schooling is often reported as an opportunity to learn stigmatization (Goffman, 1963).

For the reasons outlined above, it can be concluded that stereotypes are built socially. If this is true, it means that stigmatization and discrimination are also socially built. In these conditions for Roma students is not very easy to be included in the school activities.

\section{Problem Statement}

The Roma population is found throughout the European continent, being one of the largest but vulnerable minorities (Messing, 2008).

A significant problem is the lack of knowledge of the number of Roma in Romania. There are no precise data on the number of Roma without documents and those who do not want to declare their identity. These burdens make it harder to research the situation of this minority in Romania.

In the last decade, the Romanian government has adopted policies and programs to improve Roma situations, including education for young Roma (Open Society Institute, 2007). Various national laws on equal opportunities have been drafted, such as: The Strategy for the Improvement of the Roma Situation (HG 430/2001) adopted in 2001 and revised in 2006. In addition, in 2015 the International Roma Decade of Inclusion 20015 - 2015 (Guvernul României, 2006) has been aimed at eliminating poverty and exclusion of the Roma population. One of the four target areas of this program was Roma education. The Ministry of Education introduced a set 
of measures to curb segregation and reintegrate excluded children into public education and last but not least to reduce school dropout among Roma pupils. Among the programs that favor the improvement of the Roma education situation in Romania are also the ZEP programs. In general, educational programs in Priority Areas (ZEP) aim at: eradication (reduction) of illiteracy; providing basic education for young people from socio-economically disadvantaged backgrounds; facilitating their professional insertion.

Lately, there has been a growing interest in preventing and alleviating the phenomena of absenteeism, abandonment and non-schooling of the Roma population (Ministerul Educației şi Cercetării, 2002).

Unfortunately, throughout Europe, including Romania, Roma people are excluded from many areas of social life, being deprived of some rights and living in poverty (Open Society Institute, 2007). In this context, less favorable to a decent living, Roma students still face problems with access to quality education.

Roma people have social problems, poverty, lack of education, lack of identity papers, lack of housing, etc. Illiteracy is a serious problem for Roma population in Romania. In general Roma children do not attend the school because of poverty, migration, segregation, etc. The low level of young educated facilitates the lack of free access to health services, bad lifestyle, and discrimination (Tarnovschi, Serban, \& Preoteasa, 2012)

From the data provided in one research (Tarnovschi, Serban, \& Preoteasa, 2012), we found that the level of education of the Roma population is still low, half being primary school graduates and one quarter of the population being illiterate. Under these conditions, the chances of inclusion are still low.

\section{Research questions/Aims of the research}

In this paper we aim to identify the opinions of a sample of teachers from Romanian pre-university schools in Bucharest and 7 counties (Ilfov, Prahova, Dâmbovița, Vâlcea, Brăila, Ialomița, Călăraşi) regarding inequalities of Roma students in schools in Romania. Specifically, we propose to identify teachers' views on the situation, sometimes discriminatory, of Roma pupils in schools, as well as ways of preventing and managing existing inequalities. 


\section{Research Methods}

We used both quantitative and qualitative methods. The research tools were the questionnaire survey and the semi-structured individual interview.

Thus, we designed and applied a 14-question questionnaire with closed-ended questions, allowing respondents the opportunity to express their views.

We also used the interview where the teachers could express their personal opinions regarding the inequalities / discrimination of Roma students in schools and high schools from Romania. From the interpretation of results the structure of questionnaire and interview can be easily be deducted. Therefore we are not going to reproduce it in this part.

\section{Sampling}

The sample consisted of 101 respondents from high schools and secondary schools, from rural and urban areas in Romania. We used snowball sampling. There were 94 teachers for the survey and 7 teachers for interview.

The teachers that have participated to the research were from 67 secondary and high schools, in Bucharest and 7 counties (Ilfov, Prahova, Dâmbovița, Vâlcea, Brăila, Ialomița, Călăraşi).

\section{Findings and discussions}

\subsection{Knowledge of Romanian legislation regarding equality of chances}

The teachers who have participated at research have mentioned the presence of Roma pupils in schools, the proportion being 98\%. One item from the beginning of the survey was concerning about the knowledge of the Romanian legislation regarding equality of gipsy students chances in schools. About 76\% from teachers know the Romanian legislation about the equality for chances to the Roma students, $10 \%$ of them have a contrary opinion, while $13 \%$ of them don't know it. From the data presented both in the results of the questionnaire and the answers from the interview, it is clear that most of the teachers know the legislation that emphasizes the equality of the educational opportunities but also tries to apply it, obviously, to the benefit of the Roma students. 


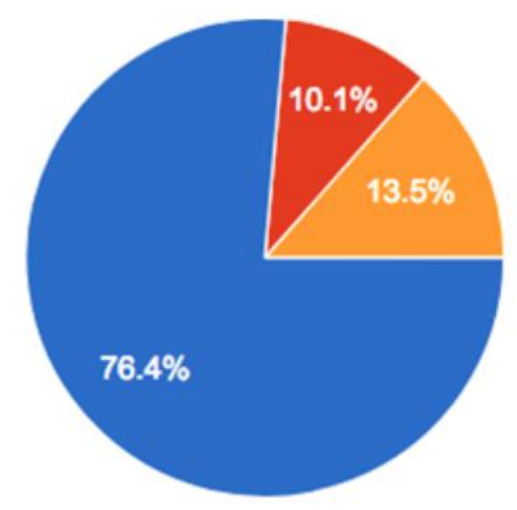

Figure 1. Teachers' feedback concerning the knowledge of Romanian legislation regarding equality of chances

\subsection{Promotion of good students - independent of ethnic origin and school skills}

Almost all of the respondents $(99 \%)$ think that promotion of good students is made independent of their ethnic origin. Respondents consider that Roma students can be praised for the willingness to bypass their condition, participation in extra-curricular activities, that many of them are ambitious, have musical talents, creativity, etc.

From the teachers' answers to the interview, we learn that many Roma students are persistent, creative, sociable, empathetic, responsible, and very cooperative in school activities. Moreover, their academic results have helped such students continue their education in high schools and universities or join companies where they are highly valued.

We mention that some Roma students are struggling to overcome their condition of poverty and marginalization, through intense study at school. There are Roma students with general media 10, which is worthy of all praise for both their families and the teachers who coordinate them.

In the schools participating at the research, Roma pupils are encouraged and appreciated for any form of school progress. The encouragements are both verbal and written, being marked according to the efforts made in the teaching.

One respondent said: "Yes, there are words of praise for Roma students who have very good results in learning because we have such pupils. We encourage them verbally..., we help those who have difficulty in knowledge acquirements ... working with them and verbally support them by encouraging even the slightest progress". 
One item was concerning the disciplines where Roma students have good results. Most of the answers $(78,3 \%)$ indicate that Roma students are better in non-exact sciences (arts, music, painting, biology, foreign languages), while only $21,7 \%$ think that they are better in exact sciences. Also, Roma students are participating in school competitions on various subjects, predominantly from non-exact sciences.
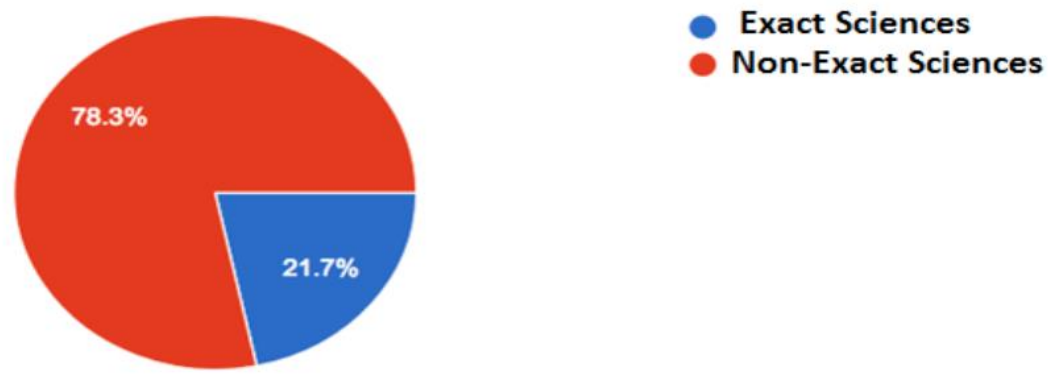

Non-Exact Sciences

Figure 2. Teachers' feedback concerning the topics where Roma students have good academic results

\subsection{Exclusion of Roma students}

More than half of the respondents (52.3\%) don't know why Roma students are excluded from different activities. Some respondents give reasons such as laziness, uncleanness, and bullying, etc.

Roma students differ in their parent's financial status. This difference entails the exclusion of poor pupils from school activities. Around $36 \%$ of respondents consider that there are differences in the school manifested by Romanian students because Roma students are either reach or poor, while $65 \%$ think that this is not the case or it is not true. The fact that more than half of respondents think that pupils do not discriminate, except in isolated cases, this helps us to conclude that the exclusion of Roma pupils is primarily due to their financial situation. 


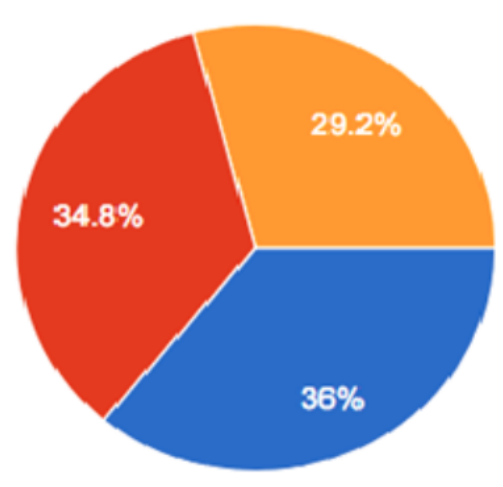

\section{- Yes \\ - No \\ It is not the case}

Figure 3. Teachers' feedback considering the exclusion of Roma students

We have found that the exclusion is only not because of the parent's financial situation, but also because of the absenteeism of Roma students. Also, Roma students self-exclude themselves - coming to school with the prejudice that they are already marginalized by colleagues and teachers. These prejudices are fueled by the attitude of their families.

\subsection{Roma students' school dropout}

More than three-quarters $(82 \%)$ of the respondents consider that there are cases of school's drop out of Roma students. Among the main reasons invoked for this are: poverty, disorganized families, parents leaving abroad, parents illiteracy, marriage at an young age, and less interest in school matters from students or parents.

The poverty and parents' illiteracy are most presented as main reasons of school's drop out. Many children from this kind of families do not attend the school even if they would like to continue to be students. In many Roma families there is no interest for education, which is reflected in their children. 

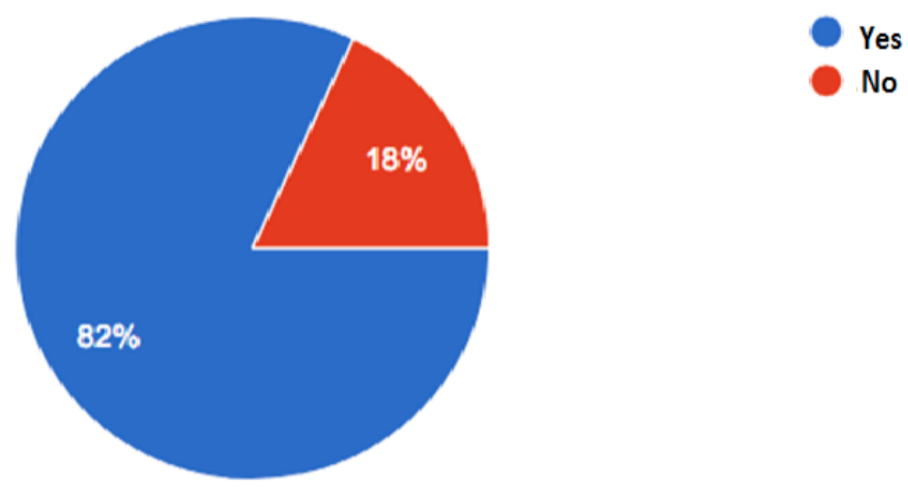

No

Figure 4. Teachers' feedback regarding the Roma students' school dropout

\subsection{Programs to help Roma students to be integrated in schools}

Two-third of respondents indicate that they organized programs for better integration of Roma students. Also, most of the answers (69\%) indicate that there are counseling programs in place to help Roma students that claim that they are discriminated.

Most of the respondents $(66,3 \%)$ consider that there are programs in place to help against discrimination.

In the participating schools, integration programs are being developed with different themes such as interculturality or comedy competitions where both Romanian and Roma students are present.

In addition, Roma students benefit from additional free meditation programs at mathematics, Romani and Romanian languages.

\section{students}

6.6. Methods of preventing the discrimination of Roma

Among the methods that are used to prevent discrimination, the following are enumerated:

- Promotion of the Roma students in the school with good results;

- Treating all pupils in a non-discriminatory manner by the teachers;

- Work in mixt ethnic groups;

- Work with the teachers for promoting equality of chances;

- Participations to competitions, excellence centers;

- Counseling activities for Roma students' families;

- Increase teacher responsibility towards discrimination, monitor educational system status for early crisis prevention, and periodic identification of changes in school dropout factors; 
- Roma students learn in classes where they are also Romanian students, participate in joint activities. Students are organized on teams that include pupils of both ethnicities;

- There are Romanian pupils who participate, together with the gipsy students, at the Roma language courses, the history, and tradition of the them;

- Material support of poor families;

- Collaboration with other teacher how to teach for equal opportunities.

\subsection{Methods of managing the discrimination of Roma students}

A good way is to help children understand that Roma students are human beings and must be treated as human beings.

In the schools that have participated at research there are disciplinary committees that help children to have a positive attitude towards Roma students. Although cases of discrimination are isolated, they can be solved with much tact and wisdom from teachers.

\section{Conclusions}

Although several documents, existing at national level regarding the situation of Roma in Romania, attest less successful attempts to include the Roma population in Romania, the present research highlights the positive aspects encountered in schools (67), Bucharest and 7 counties, at secondary level and high school.

Those Roma students that attend the school are very good students. They have good qualities such to be: persistent, creative, sociable, empathetic, responsible, and very cooperative in school activities. Moreover, their academic results have helped such students continue their education in high schools and universities, or join companies where they are highly valued. Roma pupils are encouraged and appreciated for any form of school progress.

The parent's financial status entails the exclusion of poor pupils from school activities. But the exclusion is only not because of the parent's financial situation, but also because of the absenteeism of Roma students.

Many Roma students dropout from school because of many reasons: poverty, disorganized families, parents leaving abroad, parents illiteracy, marriage at an young age, and less interest in school matters from students or parents. 
The teachers try to prevent discrimination and exclusion of Roma students. They have special programs for Roma students, Romanian students, and also for parents. The counseling service is present and helps Roma students to be better integrated in the schools programs.

Further research could be done in more counties and schools.

\section{References}

Duckitt, J. (1992). The Social Psychology of Prejudice. London: Praeger Publishers, Westport;

Friedman, E., Friedman, V. A. (ed.) (2015). Romani Worlds: Academia, Policy and Modern Media. European Academic Network on Romani Studies Romanian Institute for Research on National Minorities. Retrieved from http://romanistudies.eu/news/ebook-romani-worlds/

Goffman, E. (1963). Stigma: notes on the management of spoiled identity. New York: Touchstone Book.

Kirova, A., \& Thorlakson, L. (2015). Policy, Inclusion, and Education Rights of Roma Children: Challenges and Successes in the EU and North America. Alberta Journal of Educational Research, 61(4), 371-380;

Leyens, J. P., Yzerbyt, V., \& Schadron, G. (1994). Stereotypes and social cognition. London: Sage Publications;

Messing, V. (2008). Good practices addressing school integration of Roma/Gypsy children in Hungary. Intercultural Education, 19(5), 461-473. doi:10.1080/14675980802531721;

Miskovic, M., Curcic, S. (2016). Beyond Inclusion: Reconsidering Policies, Curriculum, and Pedagogy for Roma Students. International Journal of Multicultural Education, 18(2), 1-14;

Tarnovschi, D., Serban, M., \& Preoteasa, A. M. (2012). Roma situation in Romania, 2011. Between social inclusion and migration. Romania: Fundația Soros;

Yzerbyt, V., Leyens, J. P., Schadron, G. (1997). Social Judgeability and the Dilution of Stereotypes: The Impact of the Nature and Sequence of Information. Personality and Social Psychology Bulletin, 23(12), 1312-1322. doi:10.1177/01461672972312008;

*** Amnesty International (2013). Amnesty International Report 2013. The State of the World's Human Rights. Retrieved from https://www.amnesty.org/download/Documents/16000/pol100012013e n.pdf

*** European Parliament (2015). Directorate General for Internal Policies, Policy Department C: Citizens Rights and Constitutional Affairs, Civil Liberties, justice and Home Affairs, Evaluation of the EU Framework for National Roma Integration Strategies, Retrieved from: 
http://www.europarl.europa.eu/RegData/etudes/STUD/2015/536485/I POL_STU(2015)536485_EN.pdf

*** Guvernul României (2001). Hotărâre de Guvern nr. 430/2001 privind aprobarea Strategiei Guvernului României de îmbunatatire a situatiei romilor. Monitorul Oficial al Romaniei, 252, 2001, Mai 16.

*** Guvernul României, Agenția Naţională pentru Romi (2006). Deceniul de

Incluziune a Romilor - Un An de Președinție Românească Iulie 2005 - Iunie 2006.

Retrieved from

http://www.anr.gov.ro/docs/rapoarte/Raport un an de Presedentiedeceniu $\% 20$ (ro).pdf

*** Ministerul Educației şi Cercetării, Institutul de Ştiințe ale Educației, Institutul de Cercetare a Calității Vieții, UNICEF (2002). Participarea la educație a copiilor Romi: probleme, soluții, actori.

*** Open Society Institute, EU Monitoring and Advocacy Program, Education

Support Program, Roma Participation Program (2007). Acces egal la Educatie de calitate pentru romi. 